\title{
Effects of low-density Pinus elliottii (Slash pine) afforestation on environmental conditions and native plant diversity, in the mountains of central Argentina
}

\author{
Santiago Ignacio Fiandino ${ }^{1}$ (D) | Jose Omar Plevich ${ }^{1}$ | Juan Carlos Tarico ${ }^{1}$ | \\ Cesar Nuñez $^{2}$ | Veronica Rusch ${ }^{3}$ | Javier Enrique Gyenge ${ }^{4}$
}

${ }^{1}$ Department of plant production, National University of Río Cuarto, Córdoba, Argentina

${ }^{2}$ Department of agricultural ecology, National University of Río Cuarto, Córdoba, Argentina

${ }^{3}$ Forest Ecology group, INTA EEA Bariloche, Río Negro, Argentina

${ }^{4}$ CONICET, INTA EEA Balcarce, AER Tandil, Buenos Aires, Argentina

Correspondence

Santiago Ignacio Fiandino, Department of plant production, National University of Río Cuarto, Córdoba, Argentina.

Email: sfiandino@ayv.unrc.edu.ar

Funding information

PROGRAMAS Y PROYECTOS DE

INVESTIGACIÓN (PPI); CONICET

Co-ordinating Editor: Monika Wulf

\begin{abstract}
Question: What effects do low-density afforestation with Pinus elliottii have on the site conditions and plant diversity of the mountains of central Argentina?

Location: Sierra de Comechingones, central Argentina.

Methods: We studied the species richness and diversity and the physical and chemical properties of soils, in both the non-afforested steppe (US) and the understorey of P. elliottii silvopastoral systems (SPS). Measurements were performed on three plots located in US and 18 experimental plots located in SPS, which differ in tree density (150, 250 and 450 trees/ha), pruning (with/without) and position (below - UC -, or outside - BC -, the vertical projection of the tree crown). In each plot, we measured soil variables organic matter $(O M), p H$, electrical conductivity $(E C)$, moisture content $(R H)$ and relative proportion of coarse fragments; as well as photosynthetically active radiation that reached the ground surface $\left(P A R_{i}\right)$. At the same time, a floristic survey was performed, consisting of 117 sampling plots distributed equally between treatments. Richness, diversity and evenness indices were calculated for each treatment. Then, we carried out a PCA in order to identify the differences in life forms and environmental variables across the treatments.
\end{abstract}

Results: $P A R_{i}$ and $p H$ were statistically significantly higher in US, while $E C$ and $R H$ were statistically significantly higher in SPS. Diversity indices did not differ significantly among the non-afforested steppe (US) and the patches between crowns (BC), but were significantly higher in both these treatments than below the crown (UC). The higher richness in some of the life forms and light availability clearly separated US from UC in the PCA. All the species of interest (endemic, $\mathrm{N}$-fixing, medicinal, fodder) were found in the SPS.

Conclusions: Our study indicates that the changes in site variables produced by lowdensity afforestation generate niches for some species and, simultaneously, constitute a barrier to others. However, the fact that diversity indices and the presence of the species of interest showed no differences among the between-crowns patches and the non-afforested steppe, highlights the complex environment-vegetation relationships that take place in this kind of system. 


\section{KEYWORDS}

Central Argentina, ecological effects, multivariate analysis, Pinus elliottii, plant diversity, silvopastoral systems, species richness

\section{1 | INTRODUCTION}

The extent to which afforestation with exotic species impacts plant diversity and environmental conditions remains a source of debate. Richardson and Van Wilgen (1986) indicated that the introduction of some species of the genus Pinus (including P. nigra, P. radiata and P. taeda) have affected large areas of grassland and shrubland in the Southern Hemisphere, causing changes in the dominant life forms, reducing structural diversity, increasing biomass production and reducing vegetation dynamics. These effects are a consequence of changes in the environmental conditions of the understorey, such as a decrease in the resource levels (i.e. light, soil water and nutrients), soil acidification or litter accumulation, which inhibit the establishment of the understorey species (Amiotti, Zalpa, Sánchez, \& Peinemann, 2000; Cortés, Chamorro, \& Vega, 1990; Gómez-Aparicio, Zavala, Bonet, \& Zamora, 200 9; Michelsen, Lisanework, Friis, \& Holst, 1996). In contrast, o ther authors consider that plantations may contribute to an increase of biological diversity when they are established in degraded ecosystems, without replacing natural forests (Jiménez, Spotswood, Cañadas, \& Navarro, 2015). This increase in species diversity may be explained by the creation of low-light microhabitats suitable for colonization by shade-tolerant species in otherwise high-light environments (Belsky, 1994). Thus native plant species may benefit from the habitat amelioration by trees, which buffer against high radiation and temperature and can increase soil moisture content (Fernández, Gyenge, \& Schlichter, 2007).

Therefore, the ecological consequences of the introduction of exotic species depends on complex environment-vegetation relationships, which cannot be analysed without taking into account the abiotic conditions of the site (i.e. climatic and soil characteristics) and management of the forest plantations. Several studies (Brockway \& Outcalt, 2015; Greene et al., 2016; Jiménez et al., 2015) have documented differences in biodiversity indicators according to the silvicultural management strategies applied in conifer plantations. In general, silvicultural practices such as thinning (which tends to open the canopy cover and reduce competition) promote an increase in diversity of plant species in the ground vegetation (French et al., 2008). Besides reducing competition, thinning may also reduce litter accumulation and soil acidification, since these processes intensify as canopy cover increases (Amiotti et al., 2000; Clavijo, Cornaglia, Gundel, Nordenstahl, \& Jobbagy, 2010).

In the mountain region of central Argentina, government authorities promoted the introduction of pine forests (Pinus elliottii, $P$. taeda and $P$. insigne), without considering the consequences of the replacement of the natural plant communities. Nowadays, there are 20,000 ha of forests planted between 900 and 1,600 m a.s.l., which, due to the lack of silvicultural management, produce low quality wood and do not offer forage to livestock beyond the first 10-12 years from planting (Plevich, Nuñez, Cantero, Demaestri, \& Viale, 2002). In spite of the importance of these plantations, few studies have investigated the possible changes in the structure and composition of natural vegetation due to the introduction of pine species (Amiotti et al., 2000; Cuevas \& Zalba, 2013; Giorgis, Cingolani, Gurvich, Reynero, \& Rufini, 2005), and even fewer have studied these changes under different plantation management strategies (Plevich et al., 2002). These last authors concluded that part of the floristic composition of the natural vegetation is regenerated when the P. elliotti basal area is reduced by thinning, which make it possible to establish integrated systems for the production of forage and wood (silvopastoral systems - SPS). These SPS are productive systems that seek to optimize both timber and forage productivity through intensive silvicultural management. In the mountain region, cattle breeding is based on the forage species (grasses) that grow spontaneously (Plevich et al., 2002), thus management should be oriented to maintain the herbaceous community's diversity and productivity.

The aim of this study was to evaluate how the establishment of Slash pine (P. elliottii) SPS have affected plant species diversity and composition in the mountain region of central Argentina. A second objective was to contrast the environmental conditions of the SPS understorey with these of the non-afforested steppe (US). Consequently, we studied the species richness and diversity, and the richness of life forms, as well as the physical and chemical properties of the soils, in both silvopastoral systems and the natural shrub steppe. Besides total species richness and diversity, we focused on four groups of species that are important for conservation: (a) the endemic species, because some of them are exclusive to this area; (b) the Fabaceae capable of fixing atmospheric N, due to their important role in nutrient cycles (Guo, 2001); (c) the medicinal flora, which is used by local people as medicine (Goleniowski, Bongiovanni, Palacio, Nuñez, \& Cantero, 2006); and (d) the desirable grass species for livestock grazing (Roitman \& Preliasco, 2012). This study may contribute to the development of efficient strategies of plantation management that involve conservation of the plant community's diversity and productivity.

\section{2 | METHODS}

\section{1 | Study site}

This study was carried out in a 16-year-old P. elliottii afforestation and in a neighbouring shrub steppe dominated by Baccharis aliena (Romerillal), called non-afforested steppe (US), both under similar exposure and soil conditions, and located in "Las Guindas" 
rural establishment $\left(32^{\circ} 35^{\prime} 16.8^{\prime \prime} \mathrm{S}, 64^{\circ} 43^{\prime} 45.42^{\prime \prime} \mathrm{W}, 1,000 \mathrm{~m}\right.$ a.s.I.). This place belongs to the National University of Rio Cuarto and is located in the "Sierra de Comechingones" mountains, in Córdoba, central Argentina. The climate of the region is monsoon type, with hot and wet summers, and cold and dry winters. During the period 2000-2015, average annual rainfall was $1007 \mathrm{~mm}$ (with approximately $825 \mathrm{~mm}$ in spring-summer and $182 \mathrm{~mm}$ in autumn-winter). Maximum and minimum annual average temperatures are 22.3 and $8.4^{\circ} \mathrm{C}$, respectively, with an annual mean temperature of $14.7^{\circ} \mathrm{C}$ (Rivarola, Seiler, \& Vinocur, 2015).

The topography is characterized by a mountain environment, where hills and slopes (50\%), valleys and concavities (30\%) and rocky outcrops (20\%) are found. The areas of hills and slopes occupy a greater proportion of the surface, and it is on these areas where the pine plantations were developed. The average slope in these units is around $10 \%$ and the predominant soils are lithic, shallow $150 \mathrm{~cm}$ deep), excessively drained and very stony (Jarsún et al., 2006). Rocky outcrops occupy much of the surface of these types of soils. For that reason, the unit of vegetation that dominates these areas is presented in a dispersed way, as a shrub steppe called "Romerillal", where the dominant species is Baccharis aliena or "romerillo" (Suárez \& Vischi, 1997).

One year before this study (May 2014), a portion of the original P. elliottii plantation (500 trees/ha; planted removing the vegetation only in the planting hole) was transformed into SPS with three different tree densities and different pruning treatment (Appendix S2). We delimited 18 plots of $450 \mathrm{~m}^{2}$ with a wire fence, in order to avoid grazing. After that, tree density was adjusted to 450, 250 and 150 trees/ha (six plots for each density) by thinning, and in nine of the plots (three of each tree density), all trees were pruned to a height of $4.5 \mathrm{~m}$ (mean total height of the trees was $9.57 \mathrm{~m}$ ). As a result, six treatments (with three plots each) were defined: 1-450 trees/ ha without pruning, 2-450 trees/ha pruned, 3-250 trees/ha without pruning, 4-250 trees/ha pruned, 5-150 trees/ha without pruning and 6-150 trees/ha pruned. The experimental design consisted of randomized complete blocks (three blocks with six plots each), placed in a perpendicular direction to the main slope of the site. In the non-afforested steppe is the pre-existing vegetation of the experimental sites and, hence, this represents the 'control' situation to the various experimental treatments. For that reason, three sampling plots of the same size as the SPS plots were delimited with a wire fence.

\subsection{Site attribute characterization}

We randomly selected three trees in each silvopastoral system plot and established two sampling points: 1 - under the vertical projection of the tree crown (under crown or UC); and 2 - outside the vertical projection of the tree crown (between crowns or BC).

We obtained two composite samples of soil in each plot, mixing the three sub-samples of the first $20 \mathrm{~cm}$ of soil that belonged to the same position (UC/BC; approx. $1 \mathrm{~kg}$ from each subsample). In the non-afforested plots, we followed the same procedure and obtained a composite sample from three subsamples in each plot. In total, 39 composite samples of soil were collected. Gravimetric ratio of coarse particles $(C P)$ was determined from the dry soil samples. The samples were oven-dried at $105^{\circ} \mathrm{C}$ for $48 \mathrm{hr}$, and then sieved with 4- and 2-mm sieves, to separate three different fractions: 1 - large fragments and gravels (diameter $>4 \mathrm{~mm}$ ), 2 small gravels (diameter 2-4 mm) and 3 - proper soil particles (particles <2 mm; Etchevehere, 1976). Each of the fractions (gravels, small gravels and soil) was weighed with an analytical balance, and the values of each component expressed as a percentage of the total weight of the sample.

An aliquot of the sample was dried outdoors and used to determine: soil organic matter content $(O M)$ with the Mebius method (1960), and $\mathrm{pH}$ and electrical conductivity (EC) using an Ati-Orion 550 electric conductivity meter and a HANNA PH 211 pH-meter, respectively (1:2.5 soil/distilled water).

Soil water content was estimated from samples of the first $20 \mathrm{~cm}$ of soil, obtained at the same sampling points using a soil auger, at four different times at intervals of 1 month from midSep 2015. These samples were first weighed in moist condition, and then oven-dried at $105^{\circ} \mathrm{C}$, in order to obtain the gravimetric moisture content as weight difference. As the gravimetric moisture content varied widely according to the date on which it was obtained, water gravimetric data (percentages) were transformed into relative water content $(R H)$, using the average moisture content of each date.

$$
R H=\frac{S W C i}{S W m}
$$

where SWCi was soil water content of the i sample (\%) and SWm was average soil water content of the sampling date (\%).

We measured the incident photosynthetically active radiation (PARi) both in the non-afforested steppe and the silvopastoral systems. In under both crowns and between crowns positions, two measurements were performed: 1 - in UC, one at the northern and the other at the southern portion of the crown; and 2 - in $B C$, outside the vertical projection of the crown, north and south from the reference tree. After that, the values obtained under the same tree were averaged. Data were collected on a cloudy day (25 Mar 2015), from 09:00. to 17:00 hr using a Li-Cor sensor (LI-190 Quantum sensor; Li-Cor, Lincoln, NB, US). The interval between measurements was $2 \mathrm{hr}$. Besides the absolute value of PARi, the results obtained in each position were expressed as a proportion of the radiation recorded on the same day and time in the control situation (US).

\section{3 | Floristic composition analysis}

The floristic composition of the ground vegetation was evaluated using a square frame of $1 \mathrm{~m} \times 1 \mathrm{~m}$ in sampling points associated with the selected trees. This quadrat size was adequate for assessing both the ground vegetation of the SPS and of the US, because the contained shrubs were relatively small (average height of $0.5 \mathrm{~m}$ ) and did 
not differ significantly from the size of tussock grasses (Appendix $\mathrm{S} 2)$.

Within each frame, the percentage cover of all vascular plant species was estimated according to a six-class cover scale, according to a modification of Braun-Blanquet (1950) scale ( $1=<5 \%, 2=6-10 \%$, $3=10-25 \%, 4=25-50 \%, 5=50-75 \%, 6=75-100 \%)$.

The floristic surveys were carried out in early autumn (April). The lists of species are presented in the Appendix S1. For plant nomenclature, we followed Zuloaga, Morrone, and Belgrano (2008), and we used the Southern Cone Vascular Plants Catalog in its online version (www.darwin.edu.ar) to check for updates of names and abbreviations. We considered as local endemic species those that grow only in the province of Córdoba and as national endemic species those that have a wide distribution in Argentina. The life forms of the identified species were established according to Giorgis et al. (2011), who established the following categories: trees $(T)$, shrubs $(S)$, globular Cactaceae (GC), vines (V), annual herbs $(A H)$, ferns $(F)$, deciduous perennial herbs $(D P)$, evergreen perennial herbs $(E P)$, graminoids $(G)$ and tussock grasses (TG). Graminoids includes every annual herb that is similar in shape to a Poaceae, except for those that grow in clumps, which are included in TG. Annual herbs include every annual herb that is not a graminoid. In addition to the endemic species, other species of interest were identified in relation to: 1 - their capacity to fix atmospheric N; 2 - their medicinal properties (Goleniowski et al., 2006); and 3- their preference for cattle (Roitman \& Preliasco, 2012).

The values of diversity (Shannon index, $H^{\prime}=-\Sigma(P i \times \ln P i)$, where $\mathrm{Pi}$ is the probability of occurrence of the $i$-th species in each plot, Shannon 1948), richness (S, number of species) and equitability $\left(E=H^{\prime} / \ln S\right)$ were calculated for each of the treatments.

\section{4 | Statistical analysis}

The statistical comparisons of the calculated indices (richness, diversity and equitability) and the measured environmental variables were carried out with an ANOVA, using the LMM module in Infostat statistical software (Di Rienzo et al., 2013); and means were compared through the post-hoc Fisher LSD test. The richness differences, in terms of life forms and species of interest, were analysed by using the Kruskall-Wallis test, and then Wilcoxon test.

We carried out a PCA using several variables (Table 1) in order to identify the differences in life forms and environmental variables across the three main treatments. Multivariate analyses were performed with the statistical software InfoStat (Di Rienzo et al., 2013).

\section{3 | RESULTS}

\subsection{Characterization of site attributes}

There were no statistical differences in $\mathrm{CP}$ and $\mathrm{OM}$ between the silvopastoral systems and the non-afforested steppe (Table 2). Within the SPS, no differences were found in these variables among treatments.

In contrast, both soil $p H$ and EC were statistically different between the SPS and US (Table 2). In addition, statistically significant differences were found in the RH between the SPS and US, being 14\% higher in SPS (Table 2). However, no statistically significant differences were found between SPS treatments in any of these variables.

The amount of PARi was statistically different between the SPS and US, and between treatments within the SPS $(p<0.05)$. There was an interaction between the pruning treatment and both the position and density of plant treatments, so they were analysed together (Table 3).

On average, PARi in the US was almost double the mean level reached in the SPS ground vegetation. Besides, there were also differences between treatments within the SPS. The BC position receives an average of $25 \%$ more PARi than the UC position, although this difference is smaller in the pruned situation. PARi in the 150 trees/ha treatment was statistically significantly higher than in the 250 trees/ha treatment, and pruning had no effect on $P A R i$ in either case. In contrast, the unpruned plots receive $24 \%$ less PARi than the pruned ones in the 450 trees/ha treatment (Table 3).

TA B LE 1 Environmental variables and life form variables used in the PCA

\begin{tabular}{ll} 
Variable & Acronym \\
\hline Photosynthetically active radiation & $P A R_{i}$ \\
$\mathrm{pH}$ & $\mathrm{pH}$ \\
Relative water content & $R H$ \\
Shrub richness & $\mathrm{S}$ \\
Vine richness & $\mathrm{V}$ \\
Annual herb richness & $\mathrm{AH}$ \\
Fern richness & $\mathrm{F}$ \\
Deciduous perennial herb richness & $\mathrm{DP}$ \\
Evergreen perennial herb richness & $E P$ \\
Graminoid richness & $\mathrm{G}$ \\
Tussock grass richness & $\mathrm{TG}$
\end{tabular}

TAB LE 2 Gravimetric ratio of coarse particles (CP, \%), soil organic matter content $(O M, \%)$, electrical conductivity $(E C, \mu S / \mathrm{cm})$, $\mathrm{pH}$ and relative water content $(\mathrm{RH})$ according to management system (SPS = silvopastoral system, US = non-afforested steppe)

\begin{tabular}{|c|c|c|c|c|c|}
\hline \multirow[b]{2}{*}{ Site variable } & \multicolumn{2}{|l|}{ SPS } & \multicolumn{2}{|l|}{ US } & \multirow[b]{2}{*}{$p$-Value } \\
\hline & Mean & CV (\%) & Mean & CV (\%) & \\
\hline CP (\%) & 61.75 & 22.8 & 65.88 & 2.55 & ns \\
\hline OM (\%) & 1.92 & 36.79 & 1.67 & 54.00 & ns \\
\hline $\mathrm{EC}(\mu \mathrm{S} / \mathrm{cm})$ & 60.28 & 31.18 & 37.50 & 28.42 & $* *$ \\
\hline $\mathrm{pH}$ & 5.71 & 2.85 & 5.95 & 0.54 & * \\
\hline $\mathrm{RH}$ & 1.00 & 39.87 & 0.86 & 25.77 & $* *$ \\
\hline
\end{tabular}

Note. Statistical difference between treatments as a result of Fisher LSD test: $\left.{ }^{*} p<0.05,{ }^{* *} p<0.01\right) . p H$ means and analyses were performed on anti-logged data. 


\section{2 | Floristic characteristics of treatments}

The sites vascular flora was represented by 120 species distributed in 37 families and 95 genera (Appendix S1). In general, the values of richness and diversity were higher in between crown position and in the non-afforested steppe, than under the crown (Table 4). However, equitability showed no statistically significant differences between treatments (Table 4). No differences were found in these variables among plant density and pruning treatments.

The most important life forms were evergreen perennial herbs (39 species), graminoids (30 species), deciduous perennial herbs (15 species) and shrubs (15 species); and the less represented were trees, annual herbs, vines, cacti and ferns (Appendix S1).

As expected, in those life forms where richness was different between treatments, it was higher in the BC position and in the US than in UC position (Table 5). Nevertheless, graminoids were better represented in the $\mathrm{BC}$ position than in the rest of the treatments, while vines were better represented in the US (Table 5).

The PCA results (Figure 1 ) indicate eigenvalues (k) of 2.96 , 1.61 and 1.38 for axes 1,2 and 3, respectively. The first axis accounts for $26.9 \%$ of the variance and is explained mainly by $P A R_{i}$, and annual herbs and shrub stratum (factor scores of 0.43 , 0.43 and 0.42 , respectively); the second axis accounts for $14.7 \%$ of the variance and is explained mainly by the $\mathrm{pH}$ and the fern stratum (factor scores of 0.64 and 0.58 , respectively); and the third axis accounts for $12.5 \%$ of the variance and is explained mainly by relative humidity and graminoids (factor scores of 0.58 and 0.42 , respectively). UC plots showed more variability in axes 1 and 3, regarding differences in $P A R_{i}, A H, S$ and $G$ (Figure $1 \mathrm{~b}$ ). BC plots showed more variability in relation to axes 1 and 2 (Figure $1 \mathrm{a}$ ), as a consequence of $P A R_{i}$ and $p H$. Finally, US plots showed some variability in axis 1 , which might be related to $A H$ and $S$ richness.

TAB LE 3 Incident photosynthetically active radiation (PARi, $\mu \mathrm{mol} \mathrm{m} \mathrm{m}^{-2} \mathrm{~s}^{-1}$ ) according to the vegetation cover (SPS = silvopastoral system, US = non-afforested steppe), tree density (150, 250 and 450 trees/ha), position (under and between vertical projection of the crown, UC and BC, respectively) and pruning (pruned/not pruned) levels

\begin{tabular}{llll} 
& $\begin{array}{l}\text { Density } \\
\text { (trees/ha) }\end{array}$ & Pruned (PARi) & $\begin{array}{l}\text { Not pruned } \\
\text { (PARi) }\end{array}$ \\
\hline SPS & 150 & $173.51 \mathrm{~b}$ & $163.67 \mathrm{~b}$ \\
& 250 & $148.27 \mathrm{c}$ & $151.97 \mathrm{c}$ \\
& 450 & $161.32 \mathrm{bc}$ & $130.28 \mathrm{~d}$ \\
& UC & $149.29 \mathrm{c}$ & $128.00 \mathrm{~d}$ \\
& BC & $172.78 \mathrm{~b}$ & $169.28 \mathrm{~b}$ \\
\hline
\end{tabular}

Note. Different letters indicate statistical differences between treatments $(p<0.05)$.

\subsection{Study of the species of interest}

The endemic flora included 20 species, of which two were local endemic species (Alternanthera pumila and Bulbostylis juncoides), and 18 were national endemic (Appendix S1). In the non-afforested steppe, we found ten endemic species, while in the SPS, we found the 20 endemic species in the combined SPS treatments (17 in UC and 15 in BC; Table 6). We did not find statistically significant differences in the mean numbers of endemic species per sample plot (Table 6).

Six legume species with the capacity to fix atmospheric $\mathrm{N}$ were identified. Four of them were found both in the SPS and US (Table 6), while Adesmia incana was found exclusively in the SPS, and Senna aphylla only appeared once in the non-afforested steppe (Appendix S1). The mean numbers of legume species per sample plot were statistically significantly higher in the US than in the SPS treatments (Table 6).

The number of grass species (Poaceae) was higher in the SPS than in the US (Appendix S1). Eight grass species with a frequency $>7 \%$ were common to all treatments, whereas eight appeared only in SPS (Table 1, Appendix S3). Further, the mean numbers of highly selected Poaceae per sample plot were statistically significantly higher in both BC and UC than in US (Table 6).

Moreover, 16 species with medicinal properties were identified (Appendix S1), of which five had a frequency $>4 \%$ (Table 2, Appendix S3). All the identified medicinal species were found at least once in the SPS, including those rare or very rare species (less frequent) that did not appear in the non-afforested steppe (Appendix S1). Between crowns, the mean numbers of medicinal species per sample plot were statistically significantly higher than under the crown, while in the non-afforested steppe the mean numbers of medicinal species were not statistically different to those of either BC or UC (Table 6).

\section{4 | DISCUSSION}

\section{1 | Microenvironment differences between the silvopastoral systems and the non-afforested shrub steppe}

The top ography, soil particle size and rockiness did not differ significantly between the non-afforested steppe and the silvopastoral systems. This suggests that the differences between the measured site variables were a result of the effect of the trees. Shading is the most important of the direct effects and, in many cases, reduces the growth of the ground vegetation species because of competition for light (Sharrow, 1999); but, at the same time, shading may decrease water loss (facilitation) within the systems (Fernández et al., 2007). This facilitation process might not only be a result of a lower evapotranspiration due to shading, but also a consequence of the lower incidence of wind, caused by the presence of trees (Chen, Franklin, \& Spies, 1995). Furthermore, the presence of trees decreases surface run-off and increases infiltration (Rios, Andrade, \& Ibrahim, 2008). However, the effects of competition and facilitation on plant diversity depend on the ecophysiological characteristics of the species. Thus, the balance of the two processes defines the presence of 
certain species in each condition (treatments), which highlights the importance of determining the key site attributes.

Authors such as Amiotti et al. (2000) also found changes in soil acidity $(\mathrm{pH})$ after the introduction of pines, and found that acidification followed a defined spatial pattern, with higher $\mathrm{pH}$ values near the base of the trees (UC) than between crowns. Unlike these authors' results, we did not find significant differences in the $\mathrm{pH}$ between UC and $\mathrm{BC}$ positions. Considering this, the different patterns of $\mathrm{pH}$ could be due to the age and management of the plantations, since they are young and have a relatively low tree density, and it may take longer than 16 years for these soils characteristics to develop (Urrego, 1997).

\subsection{Differences in floristic composition, species richness and diversity between the silvopastoral systems and the non-afforested steppe}

This work focused on the effect of the introduction of pines within the ground vegetation of plantations under particular management conditions, since the characteristics of the proposed SPS differ greatly from those of the rest of the pine forests planted in the region, as well as from those of the original vegetation (Romerillal). The results suggest

TAB LE 4 Richness $(R)$, diversity $\left(H^{\prime}\right)$ and equitability $(E)$ for each position (BC = between crowns, UC = under crowns) and for the non-afforested steppe (US)

\begin{tabular}{llll} 
& $\boldsymbol{R}$ & $\boldsymbol{H}^{\prime}$ & $\boldsymbol{E}$ \\
\hline BC & $31.61 \mathrm{a}$ & $3.18 \mathrm{a}$ & $0.91 \mathrm{a}$ \\
US & $31.33 \mathrm{a}$ & $3.14 \mathrm{a}$ & $0.92 \mathrm{a}$ \\
UC & $24.33 \mathrm{~b}$ & $2.95 \mathrm{~b}$ & $0.93 \mathrm{a}$ \\
$\mathrm{R}^{2}$ & 0.69 & 0.54 & 0.19 \\
CV (\%) & 13.55 & 5.27 & 2.22 \\
\hline
\end{tabular}

Note. $R^{2}$ = coefficient of determination. Different letters indicate significant differences between treatments $(p<0.05)$. significant changes in the floristic composition of the original plant community regarding the SPS understorey; and these changes are undoubtedly associated with presence of the pines. First of all, the shrub that dominates the upper vegetation stratum in the Romerillal (B. aliena) is very rare in the SPS, appearing only in open sunlit areas within the plantations. This fact would seem to indicate that the PARi incident upon the ground vegetation of the SPS (50\% less than in the non-afforested steppe) would strongly limit its development.

This shading condition offers an adequate environment for some of the native species that are not found in the US, because of similarities in micro-environmental conditions between the SPS and the "Bosque serrano" (mountain indigenous forests) (Giorgis et al., 2005). The indigenous forests dominated by Lithrea ternifolia (Gill) and Zanthoxylum coco (Gillies ex Hook. f. \& Arn.) are open woodlands from 850 to $1150 \mathrm{~m}$ a.s.l., at the same altitude as the Romerillal (Cabido, Carranza, Acosta, \& Páez, 1991). Species that were found only in the SPS, like Colletia spinosissima, Stevia satureiifolia, Bothriochloa spp., have been classified by authors such as Cabido et al. (1991) and Oggero and Arana (2012) as species that grow in the ground vegetation of the Bosque serrano but not in the B. aliena shrubland. Furthermore, the decrease in $P A R_{i}$ coupled with higher soil moisture might explain why shade-tolerant species were mainly found in the SPS treatments. Within these species, Acalypha communis might be used as an indicator of environmental changes, since it normally grows in the wooded areas of the Americas, and was found in all the SPS treatments, but not in the US (Vaieretti, Pérez Harguindeguy, Gurvich, Cingolani, \& Cabido, 2005).

Sixteen years after the afforestation with P. elliottii, the ground vegetation richness and diversity of species was significantly higher between crowns than under crowns, but similar between BC and the non-afforested steppe. Moreover, there were also differences in herbaceous cover between UC and BC, which might have led to a decrease in total biomass productivity of the undergrowth (Guevara Escobar, Cervantes Jiménez, Suzán Azpiri, González Sosa,

\begin{tabular}{|c|c|c|c|c|}
\hline \multirow[b]{3}{*}{ Life forms } & \multicolumn{4}{|c|}{ Species richness ( $R$ ) } \\
\hline & \multirow{2}{*}{$\frac{U C}{\text { Mean (SD) }}$} & \multirow{2}{*}{$\frac{\mathrm{BC}}{\text { Mean (SD) }}$} & \multirow{2}{*}{$\frac{\text { US }}{\text { Mean (SD) }}$} & \multirow[b]{2}{*}{$p$} \\
\hline & & & & \\
\hline Annual herbs & 0.33 b (0.49) & $1.28 \mathrm{a}(0.75)$ & $2.00 \mathrm{a}(1.00)$ & $* * *$ \\
\hline $\begin{array}{l}\text { Deciduous perennial } \\
\text { herbs }\end{array}$ & $1.22 \mathrm{a}(1.26)$ & $1.78 \mathrm{a}(1.06)$ & $2.33 \mathrm{a}(0.58)$ & ns \\
\hline $\begin{array}{l}\text { Evergreen perennial } \\
\text { herbs }\end{array}$ & $7.94 \mathrm{~b}(1.98)$ & 11.39 a (3.52) & 10.67 a (0.58) & $* *$ \\
\hline Ferns & $1.00 \mathrm{a}(0.59)$ & $1.56 \mathrm{a}(0.86)$ & $1.00 \mathrm{a}(0.00)$ & ns \\
\hline Globular Cactaceae & 0.28 a $(0.46)$ & 0.11 a $(0.32)$ & 0.67 a (0.58) & ns \\
\hline Graminoids & 9.39 b (1.50) & $10.50 \mathrm{a}(1.10)$ & 7.67 b (1.53) & $* *$ \\
\hline Shrubs & 1.78 b (0.81) & 2.89 a (1.41) & 3.67 a (0.58) & ** \\
\hline Tussock grasses & 1.83 a (0.79) & $1.72 \mathrm{a}(0.83)$ & $1.00 \mathrm{a}(0.00)$ & ns \\
\hline Vines & $0.89 \mathrm{~b}(0.76)$ & $1.06 \mathrm{~b}(0.80)$ & $2.33 \mathrm{a}(0.58)$ & * \\
\hline
\end{tabular}

TABLE 5 Species richness $(R)$ of the most represented life forms, for each position ( $B C=$ between crowns, $\mathrm{UC}=$ under crowns) and for the nonafforested steppe (US)

Notes. Different letters indicate significant differences between treatments $(p<0.05)$.

Significance of the Wilcoxon test: ${ }^{*} p<0.05,{ }^{* *} p<0.01,{ }^{* * *} p<0.001$ ). 

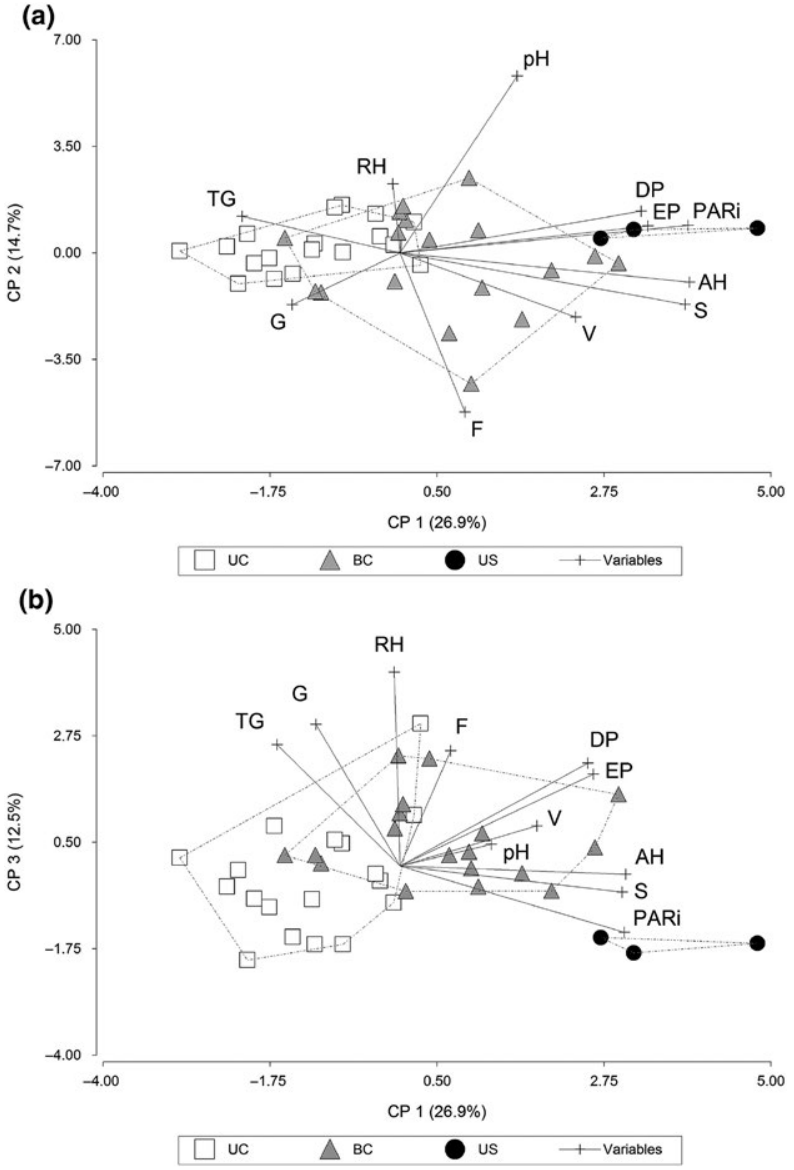

FIGURE 1 Differences in life form and environmental variables across the three main treatments through PCA ordination. Under the crown (UC, open square), between crowns (BC, filled triangle), non-afforested steppe (US, filled circle). Photosynthetically active radiation $\left(P A R_{i}\right) ; p H$; relative water content $(R H)$. Life forms: shrubs $(\mathrm{S})$, vines $(\mathrm{V})$, annual herbs $(\mathrm{AH})$, ferns $(\mathrm{F})$, deciduous perennial herbs (DP), evergreen perennial herbs (EP), graminoids $(G)$ and tussock grasses (TG)

\& y Saavedra, 2012), which is not only explained by the decrease in $P A R_{i}$, but also by a poor establishment of new seedlings in UC. Clavijo et al. (2010) have documented that under trees of most forests and plantations (UC), understorey recruitment is limited by litter accumulated on the ground.

The SPS alternatives described in this work have a spatially heterogeneous configuration, since they present different patch sizes, and some relatively open areas (especially in the lower plant density treatments). For this reason, harvesting operations should be arranged as a combination of silvicultural systems that would permit maintenance of that heterogeneity, and contribute to increased species richness and diversity (Kerr, 1999). This heterogeneity is what defines between-crown positions and gives to SPS the capacity to enhance richness, not just in terms of species, but also in terms of life forms. We did not find variation in most of life form richness when BC position and US were compared, although there were differences when compared with UC. Graminoids (Table 5) had higher richness values in the $\mathrm{BC}$ position, which do not coincide with that found in high density old plantations of the region, where evergreen perennial herb and graminoid richness decreased significantly when compared with the shrubland (Giorgis et al., 2005). Therefore, our findings agree with those of other authors who have documented differences in biodiversity indicators according to the silvicultural management strategies applied in the plantations (Brockway \& Outcalt, 2015; Greene et al., 2016; Jiménez et al., 2015). Finally, the PCA ordination (Figure 1) was consistent with the results obtained by analysing differences between treatments in terms of site conditions and life forms. The higher richness of some of the life forms (especially $n$ shrubs and annual herbs; Table 5) and light availability clearly separated US from UC. Further, UC and the US showed less variability than BC, which may indicate that these treatments are easier to characterize and more homogenous than $\mathrm{BC}$. If we associate the UC position with floristic composition of older and unmanaged plantations, BC gaps are essential to provide niches for many of the plant species to develop (Kerr, 1999).

\subsection{Study of the species of interest}

The SPS represent a very important refuge for endemic species. In a study that covered the southern portion of the mountain chain of Córdoba (290.000 ha) and described every strata from 700 to $1200 \mathrm{~m}$ a.s.l., Oggero and Arana (2012) found a total of 37 endemic species in the shrub strata. Although our study only included a single shrubland type (Romerillal) both in its natural condition and after low density pine afforestation, we were able to find 20 endemic species in the SPS (Appendix S1), which represents more than a half of the species found in the above-mentioned publication (Oggero \& Arana, 2012). This may indicate that this type of system allows growth and conservation of these valuable species.
TABLE 6 Richness (Total) of each group of species of interest per habitat type $(B C=$ between crowns, $U C=$ under crowns, and US = non-afforested steppe) and mean number of species per sample plot (Mean)

\begin{tabular}{|c|c|c|c|c|c|c|c|}
\hline & \multicolumn{2}{|l|}{ UC } & \multicolumn{2}{|l|}{ BC } & \multicolumn{2}{|l|}{ US } & \multirow[b]{2}{*}{$p$} \\
\hline & Mean (SD) & Total & Mean (SD) & Total & Mean (SD) & Total & \\
\hline Endemics & 3.83 a (1.62) & 17 & 3.89 a (1.41) & 15 & 4.67 a (1.22) & 10 & Ns \\
\hline $\begin{array}{l}\text { Highly selected } \\
\text { Poaceae }\end{array}$ & $4.44 \mathrm{~b}(0.98)$ & 8 & 4.61 b (1.14) & 8 & $1.00 \mathrm{a}(0.00)$ & 1 & * \\
\hline Medicinal & 0.50 a (0.71) & 5 & 2.78 b (1.56) & 11 & $1.00 \mathrm{ab}(1.00)$ & 2 & $* * *$ \\
\hline Legumes & 1.06 a (0.87) & 4 & $1.06 \mathrm{a}(0.94)$ & 4 & 3.33 b (0.58) & 5 & * \\
\hline
\end{tabular}

Notes. Different letters indicate significant differences between treatments $(p<0.05)$. Significance of the Wilcoxon test: ${ }^{*} p<0.05,{ }^{* *} p<0.01,{ }^{* * *} p<0.001$. 
The Fabaceae species that can fixing atmospheric $\mathrm{N}$ (as a result of their symbiotic association with specific bacteria) may increase resilience of the systems under study, due to their important role in the nutrient cycles. Guo (2001) monitored, for four consecutive years, temporal variations in species richness, cover and biomass of component plant groups in early post-fire chaparral succession in Santa Monica Mountains, southern California. These authors found that north-facing slopes exhibited higher species richness, higher species turnover rate over time and faster vegetation recovery than south-facing slopes, and attributed this to higher species richness and biomass of $\mathrm{N}$-fixing species. Our results suggest that the mean number of Fabaceae species per sample plot is higher in the US than in the SPS, which may have a negative impact on nutrient cycling within the systems and decrease $\mathrm{N}$ availability.

Finally, many of the identified medicinal plants and forage species were found exclusively in the SPS (Table 6). The SPS may generate a favourable environment for the growth of indigenous medicinal flora, which is of great importance, given that local people use them as medicine. In addition, people's demand for natural products with medicinal properties increases year by year (Goleniowski et al., 2006). In a study carried out in the region, Martínez (2005) reported that the average annual demand per point of sale for Achyrocline satureioides, Anemia australis, Baccharis crispa and Margyricarpus pinnatus (four of the six most frequent medicinal plants in the SPS) is between 27.73 and $77 \mathrm{~kg}$ /year. On the other hand, extensive cattle breeding is one of the most important economic activities in the region, and is based mainly on the forage species (grasses) that grow spontaneously in the grasslands and shrublands. Therefore, it is important to emphasize that many of the grasses (in particular those with an annual life cycle) appeared to have better adaptation to shading (levels of PARi near 50\%) of the SPS, than to full light conditions on the US, which coincides with results in other studies (Fernández, Gyenge, Dalla Salda, \& Schlichter, 2002). This evidence suggests that the grasses that grow in the SPS ground vegetation may be used as a strategic forage resource during periods of the year where forage supply is limited, since they have a better nutritional quality than these of the US and, hence, are more preferred by cattle. Grasses such as Piptochaetium montevidense or Paspalum nicorae constitute a strategic forage resource during the dry winters (Veneciano, 2006).

\section{5 | CONCLUSION}

The results of this study indicate that the micro-environmental conditions of the silvopastoral system ground vegetation are different to that of the non-afforested steppe. In terms of soil, there is a decrease in $p H$ and an increase in $E C$ and $R H$. This higher $R H$ is closely related to the lower penetration of $P A R_{i}$ because of the presence of trees. These changes in site variables generate niches for some species and, simultaneously, constitute a barrier to others. A clear indicator of these differences is the fact that the shrub that dominates the upper stratum in the non-afforested steppe (B. aliena) grows only under certain conditions in silvopastoral systems. Furthermore, it is important to highlight that there is a higher proportion of good quality grasses in the ground vegetation of the SPS; while in the non-afforested steppe, there is a higher proportion of grasses better adapted to direct sunlight and of lower nutritional quality. However, richness, diversity and equitability indices do not differ significantly among the betweencrown patches and the non-afforested steppe, which highlights the importance of maintaining the SPS spatial heterogeneity in order to contribute to increased diversity. As for the species of interest, each one of them was found in at least one of the treatments of the SPS, which may make the treatments a refuge for these species.

\section{ACKNOWLEDGEMENTS}

This research was funded through PPI (SECYT-UNRC) and CONICET (doctoral scholarship). The authors thank the FAV-UNRC Agrometeorology research group for providing meteorological data for the study area. We also thank the people in charge of "Las Guindas" rural establishment for their help and support.

\section{ORCID}

Santiago Ignacio Fiandino (iD http://orcid. org/0000-0003-4974-760X

\section{REFERENCES}

Amiotti, N. M., Zalpa, P., Sánchez, L. F., \& Peinemann, N. (2000). The impact of single trees on properties of loess-derived grassland soil in Argentina. Ecology, 81, 3283-3290. https://doi. org/10.1890/0012-9658(2000)081[3283:TIOSTO]2.0.CO;2

Belsky, A. J. (1994). Influences of trees on savanna productivity: Tests of shade, nutrients, and tree-grass competition. Ecology, 75, 922-932. https://doi.org/10.2307/1939416

Braun-Blanquet, J. (1950). Sociología vegetal. Buenos Aires, Argentina: ACME.

Brockway, D. G., \& Outcalt, K. W. (2015). Influence of selection systems and shelterwood methods on understory plant communities of longleaf pine forests in flatwoods and uplands. Forest Ecology and Management, 357, 138-150. https://doi.org/10.1016/j.foreco.2015.08.020

Cabido, M., Carranza, M. L., Acosta, A., \& Páez, S. (1991). Contribución al conocimiento fitosociológico del Bosque Chaqueño Serrano en la provincia de Córdoba, Argentina. Phytocoenologia, 19, 547-566. https://doi.org/10.1127/phyto/19/1991/547

Chen, J., Franklin, J. F., \& Spies, T. A. (1995). Growing-season microclimatic gradients from clearcut edges into old-growth Douglas-fir forests. Ecological Applications, 5, 74-86. https://doi.org/10.2307/1942053

Clavijo, M. P., Cornaglia, P. S., Gundel, P. E., Nordenstahl, M., \& Jobbagy, E. G. (2010). Limits to recruitment of tall fescue plants in poplar silvopastoral systems of the Pampas, Argentina. Agroforestry Systems, 80, 275-282. https://doi.org/10.1007/ s10457-010-9329-4

Cortés, A., Chamorro, C., \& Vega, A. (1990). Cambios en el suelo por la implantación de praderas, coníferas y eucaliptos en un área aledaña al embalse del Neusa (páramo de Guerrero). Biol Suelo, 2(1), 101-114.

Cuevas, Y. A., \& Zalba, S. M. (2013). Efecto del tipo de corte y de tratamientos en el mantillo para la restauración de pastizales naturales invadidos por Pinus halepensis. Boletín de la Sociedad Argentina de Botánica, 48, 315-329.

Di Rienzo, J. A., Casanoves, F., Balzarini, M. G., Gonzalez, L., Tablada, M., \& Robledo, C. W. (2013). InfoStat versión. Grupo InfoStat, FCA, 
Universidad Nacional de Córdoba, Argentina. Retrieved from http:// www.infostat.com.ar

Etchevehere, P. H. (1976). Normas de reconocimiento de suelos. 2nd ed. updated. INTA, Dpto. de Suelos. Publicación, (152).

Fernández, M. E., Gyenge, J. E., Dalla Salda, G., \& Schlichter, T. M. (2002). Silvopastoral systems in northwestern Patagonia. I: Growth and photosynthesis of Stipa speciosa under different levels of Pinus ponderosa cover. Agroforestry Systems, 55, 27-35.

Fernández, M. E., Gyenge, J. E., \& Schlichter, T. M. (2007). Balance of competitive and facilitative effects of exotic trees on a native Patagonian grass. Plant Ecology, 188, 67-76.

French, L. J., Smith, G. F., Kelly, D. L., Mitchell, F. J., O'Donoghue, S., Iremonger, S. F., \& McKee, A. M. (2008). Ground flora communities in temperate oceanic plantation forests and the influence of silvicultural, geographic and edaphic factors. Forest Ecology and Management, 255, 476-494. https://doi.org/10.1016/j.foreco.2007.09.014

Giorgis, M. A., Cingolani, A. M., Chiarini, F., Chiapella, J., Barboza, G., Espinar, L. A., ... Cabido, M. (2011). Composición florística del Bosque Chaqueño Serrano de la provincia de Córdoba, Argentina. Kurtziana, 36, 9-43.

Giorgis, M. A., Cingolani, A. M., Gurvich, D. E., Reynero, N., \& Rufini, S. (2005). Diferencias en la estructura de la vegetación del sotobosque entre una plantación de Pinus taeda L. (Pinaceae) y un matorral serrano (Cuesta Blanca, Córdoba). Kurtziana, 31, 39-49.

Goleniowski, M. E., Bongiovanni, G. A., Palacio, L., Nuñez, C. O., \& Cantero, J. J. (2006). Medicinal plants from the "Sierra de Comechingones", Argentina. Journal of Ethnopharmacology, 107, 324-341. https://doi. org/10.1016/j.jep.2006.07.026

Gómez-Aparicio, L., Zavala, M. A., Bonet, F. J., \& Zamora, R. (2009). Are pine plantations valid tools for restoring Mediterranean forests? An assessment along abiotic and biotic gradients. Ecological Applications, 19, 2124-2141. https://doi.org/10.1890/08-1656.1

Greene, R. E., Iglay, R. B., Evans, K. O., Miller, D. A., Wigley, T. B., \& Riffell, S. K. (2016). A meta-analysis of biodiversity responses to management of southeastern pine forests - opportunities for open pine conservation. Forest Ecology and Management, 360, 30-39. https:// doi.org/10.1016/j.foreco.2015.10.007

Guevara Escobar, A., Cervantes Jiménez, M., Suzán Azpiri, H., González Sosa, E., Saavedra, I., (2012). Producción de pasto Rhodes en una plantación de eucalipto. Agrociencia, 46(2), 175-188.

Guo, Q. (2001). Early post-fire succession in California chaparral: Changes in diversity, density, cover and biomass. Ecological Research, 16, 471-485. https://doi.org/10.1046/j.1440-1703.2001.00410.x

Jarsún, B., Gorgas, J. A., Zamora, E., Bosnero, H., Lovera, E., Ravelo, A., \& Tassile, J. L. (2006). Recursos naturales de la Provincia de Córdoba, Los Suelos. Publ. Téc. Agencia Córdoba Ambiente SE, Córdoba, Argentina.

Jiménez, M. N., Spotswood, E. N., Cañadas, E. M., \& Navarro, F. B. (2015). Stand management to reduce fire risk promotes understorey plant diversity and biomass in a semi-arid Pinus halepensis plantation. Applied Vegetation Science, 18, 467-480. https://doi.org/10.1111/avsc.12151

Kerr, G. (1999). The use of silvicultural systems to enhance the biological diversity of plantation forests in Britain. Forestry, 72, 191-205. https://doi.org/10.1093/forestry/72.3.191

Martínez, G. J. (2005). Recolección y comercialización de plantas medicinales en el departamento Santa María, provincia de Córdoba, Argentina. Acta Farmacéutica Bonaerense, 24, 575.

Mebius, L. (1960). A rapid method for the determination of organic carbon in soil. Analytica Chimica Acta, 22, 120-124. https://doi. org/10.1016/S0003-2670(00)88254-9

Michelsen, A., Lisanework, N., Friis, I., \& Holst, N. (1996). Comparisons of understorey vegetation and soil fertility in plantations and adjacent natural forests in the Ethiopian highlands. Journal of Applied Ecology, 33, 627-642. https://doi.org/10.2307/2404991

Oggero, A. J., \& Arana, M. D. (2012). Inventario de las plantas vasculares del sur de la zona serrana de Córdoba, Argentina. Hoehnea, 39, 171199. https://doi.org/10.1590/S2236-89062012000200002
Plevich, J., Nuñez, C., Cantero, J., Demaestri, M., \& Viale, S. (2002). Biomasa del pastizal bajo diferentes densidades de pino (Pinus elliottii). Agroforestería en las Américas, 9, 19-23.

Richardson, D. M., \& Van Wilgen, B. W. (1986). Effects of thirty-five years of afforestation with Pinus radiata on the composition of mesic mountain fynbos near Stellenbosch. South African Journal of Botany, 52, 309-315. https://doi.org/10.1016/S0254-6299(16)31526-5

Rios, N., Andrade, H., \& Ibrahim, M. (2008). Evaluación de la recarga hídrica en sistemas silvopastoriles en paisajes ganaderos. Zootecnia Tropical, 26, 183-186.

Rivarola, A., Seiler, R., \& Vinocur, M. (2015). Datos climáticos de Las Guindas: serie de 15 años. Servicio de agrometeorología. FAV, UNRC, Argentina.

Roitman, G., \& Preliasco, P. (2012). Guía de reconocimiento de herbáceas de la pampa deprimida: Características para su manejo (128 pp). Buenos Aires, Fund. Vida Silvestre AR; Aves Argentinas.

Shannon, C. E. (1948). A mathematical theory of communication. Bell System Technical Journal, 27, 379-423, 623-656.

Sharrow, S. H. (1999). Silvopastoralism: Competition and facilitation between trees, livestock, and improved grass-clover pastures on temperate rainfed lands. In L. E. Buck, J. Lassoie, \& E. C. M. Fernandez (Eds.), Agroforestry in sustainable agricultural systems (pp. 111-130). Boca Raton, FL: CRC Press.

Suárez, S., \& Vischi, N. (1997). Caracterización fisonómico-estructural de vegetación serrana (Alpa Corral-Córdoba-Argentina). Multequina, 6, 21-32.

Urrego, B. (1997). La reforestación con coníferas y sus efectos sobre la acidificación, podsolización y pérdida de fertilidad de los suelos. Informaciones Agronómicas, 28, 6-12.

Vaieretti, M. V., Pérez Harguindeguy, N., Gurvich, D. E., Cingolani, A. M., \& Cabido, M. (2005). Decomposition dynamics and physio-chemical leaf quality of abundant species in a montane woodland in central Argentina. Plant and Soil, 278, 223-234. https://doi.org/10.1007/ s11104-005-8432-1

Veneciano, J. H. (2006). Gramíneas estivales perennes para ambientes semiáridos: Características y productividad (pp 171, 84). INTA San Luis, Información Técnica, AR.

Zuloaga, F. O., Morrone, O., \& Belgrano, M. J. (2008). Catálogo de Las Plantas Vasculares Del Cono Sur: (Argentina, Sur de Brasil, Chile, Paraguay y Uruguay). Monographs in Systematic Botany from the Missouri Botanical Garden, 107(I-II-III), 1-3348.

\section{SUPPORTING INFORMATION}

Additional supporting information may be found online in the Supporting Information section at the end of the article.

APPENDIX S1 List of the vascular plant species surveyed in the study area and sorted by families

APPENDIX S2 Photographs of the non-afforested steppe and the silvopastoral systems

APPENDIX S3 Characteristics of the Poaceae species and medicinal species that appeared at a higher frequency

How to cite this article: Fiandino SI, Plevich JO, Tarico JC, Nuñez C, Rusch V, Gyenge JE. Effects of low-density Pinus elliottii (Slash pine) afforestation on environmental conditions and native plant diversity, in the mountains of central Argentina. Appl Veg Sci. 2018;00:1-9. https://doi.org/10.1111/avsc.12385 


\section{Graphical Abstract}

The contents of this page will be used as part of the graphical abstract of html only.

It will not be published as part of main article.
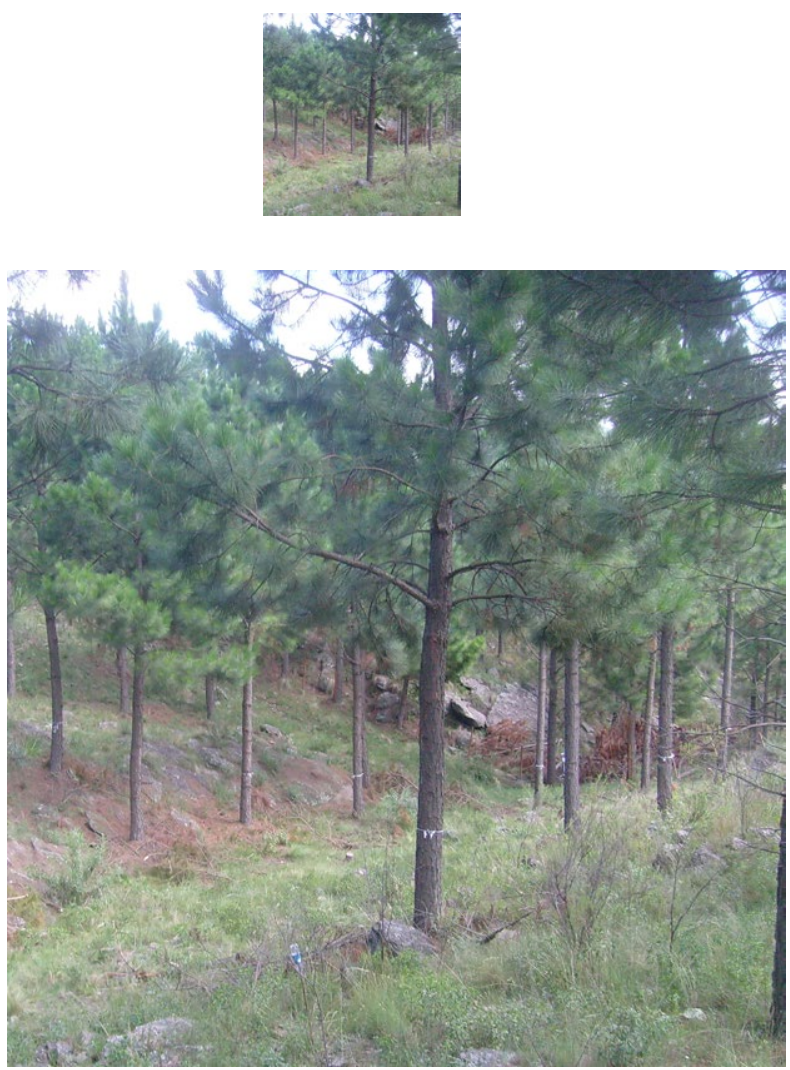

We analysed the effects of low-density afforestation with Pinus elliottii on site conditions and plant diversity in differently managed plantations of the mountains of central Argentina. We found complex environment-vegetation relationships in the systems, thus the changes in site variables generated niches for some species and, simultaneously, constituted a barrier to others. 